\title{
Ampulla of Vater Signet Ring Cell Carcinoma
}

National Cancer Institute

\section{Source}

National Cancer Institute. Ampulla of Vater Signet Ring Cell Carcinoma. NCI Thesaurus.

Code C6656.

An adenocarcinoma arising from the ampulla of Vater. Morphologically, it is

characterized by the presence of mucin-containing signet-ring cells. 